\title{
PERSEPSI LANSIA HIPERTENSI DAN PERILAKU KESEHATANNYA
}

\author{
Edy Soesanto ${ }^{1}$, Riski Marzeli ${ }^{2}$ \\ ${ }^{1-2}$ Program Studi Ilmu Keperawatan Fikkes UNIMUS \\ Email: soesantoedisoes@gmail.com
}

\begin{abstract}
ABSTRAK
Hipertensi merupakan salah satu penyumbang terbesar penyebab kematian di dunia dan menjadi masalah kesehatan public utama di seluruh dunia. Peningkatan hipertensi dalam lima tahun terakhir sebesar 8,3\% harus menjadi perhatian khusus pemerintah dalam mengatasi angka hipertensi. Salah satu faktor resiko yang harus diubah pada hipertensi adalah perilaku dan gaya hidup, mulai dari pola makan yang tidak sehat sampai kurangnya aktivitas olahraga serta persepsi individu yang keliru terhadap penyakit hipertensi. Penelitian ini bertujuan untuk melihat adanya hubungan antara persepsi lanjut usia hipertensi dengan perilaku kesehatan. Jenis penelitian ini adalah Deskriptif dengan menggunakan desain Cross Sectional. Jumlah sampel sebanyak 96 responden lanjut usia yang menderita hipertensi dan masih mampu melakukan aktivitas sehari-hari secara mandiri di desa Sumberrejo Mranggen, Demak dengan menggunakan Teknik proporsional random sampling. Alat pengumpulan data menggunakan kuesioner dan dianalisis dengan menggunakan uji rank spearman. Hasil penelitian menunjukkan bahwa terdapat 64 responden $(66,7 \%)$ memiliki perilaku kesehatan yang baik, 64 responden $(66,7 \%)$ memiliki persepsi keuntungan, 52 responden $(54,2 \%)$ memiliki persepsi hambatan dan ada hubungan antara persepsi manfaat dan persepsi hambatan dengan perilaku Kesehatan lanjut usia hipertensi dengan nilai $\mathrm{p}$ value masing-masing sebesar 0,000 dan 0,0458 (p value <0,05). Berdasarkan hasil tersebut diharapkan lanjut usia hipertensi memiliki persepsi keuntungan yang baik terhadap penyakitnya dan perilaku kesehatan yang baik agar penyakit hipertensi yang dideritanya dapat dikendalikan atau terkontrol dengan baik.
\end{abstract}

Kata Kunci: Persepsi, Lansia, Hipertensi, Perilaku Kesehatan

\begin{abstract}
Hypertension is one of the biggest contributors to the causes of death in the world and major public health problem in the world. The hypertension in the last five years of 8,3\% must be special attention the government to tackle the hypertension. One of the risks which must be changed in hypertension is a and lifestyle, ranging from unhealthy diet to lack of activity sports and an erroneous perception individuals against disease hypertension. This study attemps to see the relationship between hypertension with the behavior of elderly health. This is the kind of research using design cross sectional descriptive. The number of samples from 96 respondents age who suffers from hypertension and still be able to put up the day sumber rejo mranggen independently in the village, demak using proportional random sampling techniques. A collection of data using questionnaire and analyzed using rank spearman. Test the result showed that there are 64 respondents $(66,7 \%)$ have good health, behavior 64 respondents ( there a connection berween the perception of the benefits and perception barriers with health behavior elderly hypertension with the value of $p$ value 0,000 respectively and
\end{abstract}


o,o458 ( $p$ value <0,05). According to the elderly hypertension is expected to have perception good advantage against the disease and the behavior of good health that he sustained hypertension disease can be controlled.

Keywords : Perception the elderly, Hypertension, Health behavior 


\section{LATAR BELAKANG}

Indonesia saat ini terjadi transisi penyakit, dimana trasisi tersebut diakibatkan oleh jumlah kasus penyakit tidak menular yang melebihi angka penyakit menular. Dalam lima tahun terakhir terjadi peningkatan angka kematian akibat dari penyakit tidak menular sebesar $11 \%$ dan akan terus meningkat setiap tahunnya termasuk di dalamnya adalah penyakit hipertensi.(Oktaviani, 2015; Soesanto and Sandra Fatmawati, 2019)

Hipertensi merupakan suatu penyakit yang menjadi masalah kesehatan di seluruh dunia. Berdasarkan prediksi WHO tahun 2025 angka kejadian hipertensi di dunia pada orang dewasa mencapai $29,2 \%$. Penyakit hipertensi setiap tahunnya mengalami kenaikan di seluruh dunia. Hal ini dapat dilihat dari hasil pervalensi hipertensi di Indonesia berdasarkan hasil pengukuran tahun 2013 hingga 2018 pada penduduk yang berumur di atas 18 tahun mengalami peningkatan yang signifikan yaitu sebesar $25,8 \%$ menjadi $34,1 \%$, sedangkan prevalensi berdasarkan usia, penyakit hipertensi paling banyak diderita oleh lanjut usia yaitu antara 4575 tahun ke atas.(Kementrian Kesehatan RI, 2018) Pada usia yang semakin bertambah akan menyebabkan peningkatan tekanan darah. Hal ini diakibatkan oleh penebalan pada dinding arteri yang menyebabkan zat kolagen pada lapisan otot menjadi menumpuk sehingga pembuluh darah menjadi sempit dan kaku.(Dewi, 2014)

Berdasarkan hasil dari pengukuran tekanan darah pada tahun 2017 yang dilakukan oleh sejumlah penduduk di Jawa Tengah terdapat 8.888 .585 orang $(36,53 \%)$ memiliki resiko dan berusia diatas 18 tahun, sebanyak 1.153 .371 orang $(12,98 \%)$ dikatakan memiliki penyakit hipertensi. Kabupaten Demak merupakan kabupaten urutan nomor dua tertinggi penderita hipertensi yaitu sebanyak $76,7 \%$, dan Kota Salatiga merupakan peringkat pertama yaitu sebesar 77,72\% (Rikesdas, 2017). Prevalansi penderita hipertensi pada usia lanjut di Puskesmas Mranggen 1 kabupaten Demak tahun 2018 sebesar 3.295 penderita dan mengalami peningkatan sebesar $1 \%$ bila dibandingkan tahun-tahun sebelumnya(Soesanto and Abdurrahman, 2020).

Penyebab hipertensi digolongkan menjadi dua kelompok yaitu kelompok yang tidak bisa diubah dan kelompok yang dapat diubah. Kelompok yang tidak dapat diubah meliputi : keturunan, umur, jenis kelamin, dan etnis. Sedangkan kelompok yang bisa diubah meliputi : gaya hidup, stress, obesitas, kebiasaan merokok, konsumsi alkohol, kurangnya aktifitas fisik dan mengkonsumsi garam berlebih.(Dewi, 2014) Salah satu faktor utama yang sangat beresiko dan harus diubah yaitu perilaku atau gaya hidup, sedangkan untuk mengubah gaya hidup atau perilaku seseorang dipengaruhi oleh persepsi seseorang tersebut terhadap penyakitnya.(Soesanto et al., 2018; Soesanto and Sandra Fatmawati, 2019)

Menurut teori Health Belief Model (HBM) untuk mengubah perilaku kesehatan masyarakat maka perlu terlebih dahulu mengubah persepsi yang ada di masyarakat. Teori HBM menyebutkan bahwa terdapat 6 persepsi yang mempengaruhi perilaku yaitu persepsi kerentanan (susceptibility), persepsi keparahan (severity), persepsi keuntungan (benefits), persepsi hambatan (barriers), persepsi petunjuk untuk bertindak (coes to action) dan persepsi motivasi (self efficaci). Dari 6 persepsi tersebut, dua diantaranya merupakan persepsi yang penting untuk diketahui yaitu persepsi keuntungan (benefits) dan hambatan (barries). Karena, apabila kedua dari persepsi ini tidak diubah maka akan menyebabkan perilaku yang tidak sehat untuk penderita hipertensi.(Nugraheni, Hernien., wiyatini, tri., wiradona, 2018; Soesanto et al., 2018) Bila individu merasa rentan terhadap penyakit yang sedang dideritanya dianggap gawat (serius), maka ia akan melakukan suatu tindakan dan tindakan yang diambil tergantung pada manfaat yang dirasakan dan rintangan yang akan ditemukan dalam mengambil tindakan tersebut.(Afifa, 2019)

Berdasarkan hasil penelitian sebelumnya bahwa upaya mengendalikan Kesehatan lanjut usia hipertensi dipengaruhi adanya persepsi keuntungan dan hambatan, semakin tinggi persepsi manfaat yang lanjut usia ketahui maka upaya pengendalian kesehatannya akan 
semakin baik begitu juga sebaliknya(Soesanto et al., 2018). Penelitian lain mengatakan bahwa masih ada Sebagian lanjut usia dengan hipertensi yang memiliki perilaku kesehatan yang tidak baik seperti tidak melakukan pengobatan secara maksimal, kebiasaan merokok dan masih mengkonsumsi makanan dengan tinggi garam, mempunyai persepsi bahwa biaya periksa membebani keluarga, malas periksa kesehatan karena merasa sehat, petugas kesehatan yang tidak ramah, serta pelayanan kesehatan yang disediakan jauh dari rumah(Sulaiman et al., 2018). Hal ini juga dialami oleh Sebagian besar lanjut usia hipertensi yang ada di Desa Sumberejo. Hasil Data dari Puskesmas Mranggen Kabupaten Demak tahun 2019 dari jumlah penduduk Desa Sumberjo sebesar 8317 orang, terdapat 897 orang menderita hipertensi dan 127 penderita hipertensi adalah lanjut usia. Berdasarkan penuturan petugas kesehatan dan kader Kesehatan Sebagian besar lanjut usia masih memiliki persepsi yang keliru terhadap penyakit hipertensi sehingga berdampak terhadap upaya pemeliharaan kesehatan dan perilaku hidup sehat(Dinkes Kab. Demak, 2019).

\section{METODE PENELITIAN}

Jenis penelitian ini adalah Deskriptif korelasi dengan menggunakan desain Cross Sectional. Jumlah sampel sebanyak 96 responden lanjut usia yang menderita hipertensi di desa Sumberrejo Mranggen, Demak dengan menggunakan Teknik proporsional random sampling. Jumlah sampel terdiri dari 20 lansia hipertensi dari dukuh Karangasem, 18 lansia hipertensi dari dukuh Dukoh, 15 lansia hipertensi dari dukuh Dawung, 19 lansia hipertensi dari dukuh Puro, dan 24 lansia hipertensi dari dukuh Sendang Delik. Alat pengumpulan data menggunakan kuesioner, dianalisis dengan menggunakan uji rank spearman. Penelitian ini dilakukan pada bulan September 2020 dan sudah mendapat persetujuan dari komisi etik FKM UNIMUS dengan nomor: 393/KEPK-FKM/UNIMUS/2020.

\section{HASIL DAN PEMBAHASAN}

Karakteristik responden pada penelitian ini berdasarkan umur rata-rata 64,03 tahun, usia terendah adalah 60 tahun dan tertinggi 70 tahun $\pm 3,561$. Sedangkan menurut jenis kelamin Sebagian besar adalah perempuan sebesar 68 orang $(70,8 \%)$.

Tabel 1 Deskripsi Perilaku Kesehatan Lanjut Usia Hipertensi

\begin{tabular}{cccccc}
\hline Keterangan & Mean & Median & Minimum & Maksimum & Std. Deviasi \\
\hline Perilaku Kesehatan & 15,24 & 15,00 & 12 & 18 & 1,471 \\
\hline
\end{tabular}

Tabel 2 Distribusi Frekuensi Perilaku Kesehatan Lanjut Usia Hipertensi

\begin{tabular}{ccc}
\hline Perilaku Kesehatan & Frekuensi & Persentase (\%) \\
\hline Tidak Baik & 32 & 33,3 \\
Baik & 64 & 66,7 \\
\hline Jumlah & 96 & 100 \\
\hline
\end{tabular}

Berdasarkan Tabel 1 dan 2 dapat diketahui bahwa data berdistribusi tidak normal nilai $\mathrm{p}$ sebesar $0,000(<0,05)$. Sebagian besar responden memiliki perilaku kesehatan baik yaitu sebanyak 64 orang $(66,7 \%)$.

Tabel 3 Deskripsi Persepsi Keuntungan Lanjut Usia Hipertensi

\begin{tabular}{cccccc}
\hline Keterangan & Mean & Median & Minimum & Maksimum & Std. Deviasi \\
\hline Persepsi keuntungan & 2,90 & 3,00 & 0 & 5 & 1,071 \\
\hline
\end{tabular}

Tabel 4 Distribusi frekuensi berdasarkan Persepsi Keuntungan

\begin{tabular}{ccc}
\hline Persepsi keuntungan & Frekuensi & Persentase (\%) \\
\hline Tidak Baik & 32 & 33,3 \\
Baik & 64 & 66,7 \\
\hline Jumlah & 96 & 100 \\
\hline
\end{tabular}


Berdasarkan Tabel 3 dan 4 dapat diketahui hasil uji normalitas data menunjukan data berdistribusi tidak normal dengan nilai p sebesar 0,000 $(<0,05)$. Sebagian besar responden memiliki persepsi keuntungan yang baik yaitu sebanyak 64 orang $(66,7 \%)$.

Tabel 5 Deskripsi Persepsi Hambatan Lanjut Usia Hipertensi

\begin{tabular}{cccccc}
\hline Keterangan & Mean & Median & Minimum & Maksimum & Std. Deviasi \\
\hline Persepsi Hambatan & 4,47 & 5,00 & 2 & 7 & 0,158 \\
\hline
\end{tabular}

Tabel 6 Distribusi Frekuensi Persepsi Hambatan Lanjut Usia Hipertensi

\begin{tabular}{ccc}
\hline Persepsi Hambatan & Frekuensi & Persentase (\%) \\
\hline Tidak Baik & 44 & 45,8 \\
Baik & 52 & 54,2 \\
\hline Jumlah & 96 & 100 \\
\hline
\end{tabular}

Berdasarkan Tabel 5 dan 6 dapat diketahui bahwa hasil uji normalitas data ditemukan bahwa persepsi hambatan berdistribusi tidak normal dengan nilai p sebesar ,000 $(<0,05)$. Sebagian besar responden memiliki persepsi hambatan yang baik sebanyak 52 orang $(54,2 \%)$.

\section{Perilaku Kesehatan Lanjut Usia Hipertensi.}

Hasil penelitian didapatkan bahwa sebagian besar responden memiliki perilaku kesehatan yang baik yaitu sebanyak 64 orang $(66,7 \%)$. Perilaku kesehatan tersebut ditunjukkan responden dengan melakukan pemeriksaan tekanan darah sebulan sekali, mengkonsumsi obat hipertensi secara rutin setiap hari, mengkonsumsi sayuran hijau,sedangkan perilaku kesehatan yang masih kurang baik ditunjukkan dengan masih suka mengkonsumsi makanan yang asin dan mengandung zat pengawet serta perasa/MSG, merokok, mengkonsumsi mie instan, sarden, sosis.

Masih banyaknya lanjut usia yang mengkonsumsi makanan yang kurang sehat karena hampir sebagian besar yang memasak dirumah adalah keluarganya sehingga lanjut usia tidak ada pilihan lain untuk tidak memakannya kecuali pada lanjut usia yang tinggal dirumah sendirian. Pemahaman tentang perilaku kesehatan yang baik Sebagian besar didapatkan dari pertemuan posyandu yang setiap saat memberikan penyuluhan kesehatan. Hal ini sesuai dengan penelitian sebelumnya yang menyatakan bahwa perilaku Kesehatan merupakan suatu reaksi seseorang berdasarkan besar kecilnya tingkat pemahaman seseorang terhadap sakit dan penyakit yang dialaminya.(Husniyawati, 2016) Seseorang berperilaku sehat karena adanya motif keinginan, harapan untuk sembuh dan ingin tetap sehat serta bagaimana seseorang mampu mendefinisikan penyakitnya dengan baik dan kemampuan seseorang untuk melawan serangan penyakit tersebut.(Soesanto and Abdurrahman, 2020) Dukungan keluarga dan kader sangat berpengaruh terhadap upaya pencegahan Kesehatan lanjut usia hipertensi, lanjut usia beranggapan bahwa keluarga, kader Kesehatan merupakan seseorang yang lebih tahu tentang kesehatannya dibandingkan dengan dirinya, mereka yang membantunya dalam segala hal terkait kesehatan.(Soesanto et al., 2018)

\section{Persepsi Keuntungan}

Hasil penelitian diketahui bahwa sebagian besar responden memiliki persepsi keuntungan (perceived benefits) yang baik sebanyak 64 orang (66,7\%). Responden mempersepsikan bahwa melakukan kegiatan atau perilaku yang sehat dapat mengontrol tekanan darahnya dengan teratur, dapat mencegah terjadinya komplikasi, mengetahuicaraperawatan yang benar. Seseorang akan melakukan Tindakan tertentu untuk proses kesembuhan penyakit yang dideritanya tergantung pada manfaat yang dirasakan olehnya.(Nurmala, 2020) 
Penelitian sebelumnya juga mengatakan bahwa keuntungan merupakan efektifitas program untuk mengurangi ancaman kesehatan, keputusan untuk mengambil tindakan/upaya penanggulangan atau pencegahan penyakit itu tergantung dari persepsi individu tentang manfaat dari tindakan tersebut baginya, besar/kecilnya hambatan untuk melaksanakan tindakan itu serta pandangan individu tentang kemampuan diri sendiri. (Riani et al., 2013; Husniyawati, 2016)

\section{Persepsi Hambatan}

Hasil penelitian ini diketahui bahwa sebagian besar responden memiliki persepsi hambatan yang baik sebanyak 52 responden $(54,2 \%)$. Persepsi hambatan yang baik merupakan cara responden memiliki kesadaran untuk melakukan tindakan dan bertujuan untuk mengontrol tekanan darah. Sebagian responden mengatakan bahwa apabila dirinya melakukan perilaku Kesehatan dengan baik maka akan membebani keluarga, harus meninggalkan pekerjaan, tetapi sebagian besar merasa tidak terbebani. Penelitian sebelumnya juga menyampaikan bahwa biaya periksa membebani keluarga yang lain.(Soesanto et al., 2018) Seseorang tidak melakukan upaya kegiatan atau perilaku sehat dikarenakan takut membebani, keluarga karena harus mengeluarkan biaya pengobatan, harus meninggalkan pekerjaan karena harus menyisihkan waktunya mengantar kepelayanan kesehatan.(Soesanto, 2012)

Persepsi hambatan merupakan persepsi terhadap aspek negatif yang menghalangi individu untuk melakukan tidakan kesehatan, seperti membutuhkan usaha, biaya, waktu yang lama, pengalaman tidak menyenangkan, dan rasa sakit, sehingga salah satu dari alasan tersebut individu akan berfikir dengan melakukannya akan sulit.

\section{Hubungan Persepsi Keuntungan Lanjut Usia Hipertensi dengan Perilaku Kesehatan}

Berdasarkan uji statistik dengan menggunakan korelasi RankSpearman didapatkan nilai koefisien korelasi sebesar 0,625 dengan nilai $p$ sebesar 0,000 (nilai $p<0,05$ ) sehingga dapat dinyatakan ada hubungan yang bermakna antara persepsi keuntungan dengan perilaku kesehatan hipertensi pada lansia dan memiliki tingkat hubungan yangkuat.(Sulaiman et al., 2018) Kedua variabel menunjukkan adanya hubungan positif, artinya apabila persepsi keuntungan meningkat maka ada kecenderungan perilaku kesehatan lanjut usia hipertensi juga akan meningkat.

Perilaku seseorang terhadap penyakitnya dipengaruhi oleh bagaimana individu berespons, baik secara pasif (mengetahui, bersikap, dan mempersepsi penyakit dan rasa sakit yang ada pada dirinya dan di luar dirinya, maupun aktif (tindakan yang dilakukan sehubungan dengan penyakit dan sakit tersebut).(Syukra Alhamda and Yustina Sriani, 2015) Masyarakat atau anggota masyarakat yang mendapat penyakit, dan tidak merasakan sakit (disease but no illness) sudah barang tentu tidak akan bertindak apa-apa terhadap penyakitnya, tetapi bila individu merasa dirinya rentan untuk penyakit-penyakit yang dianggap gawat (serius), maka ia akan melakukan suatu tindakan tertentu. Tindakan ini tergantung pada manfaat yang dirasakan dan rintangan-rintangan yang ditemukan dalam mengambil tindakan tersebut. Pada umumnya manfaat tindakan lebih menentukan dari pada rintangan-rintangan yang mungkin ditemukan di dalam melakukan tindakan tersebut.(Nurmala, 2020)

Hal ini juga dirasakan oleh responden bahwa melakukan perilaku sehat sangat bermanfaat bagi dirinya, yaitu dapat mengetahui tentang penyakitnya, tekanan darahnya terkontrol, mendapatkan pengobatan, mengetahui cara pencegahan dan makanan yang dilarang serta aktivitas yang boleh dilakukan, dengan berbagai macam manfaat yang mereka dapatkan itu menjadikan lanjut usia tersebut melakukan kegiatan atau perilaku sehat secara berkala. 


\section{Hubungan Persepsi Hambatan dengan Perilaku Kesehatan pada Lanjut usia Hipertensi}

Berdasarkan uji statistik dengan menggunakan korelasi rank spearman didapatkan koefisien nilai korelasi sebesar 0,458 dengan nilai $\mathrm{p}$ sebesar 0,000 (nilai $\mathrm{p}<0,05$ ), sehingga dapat disimpulkan ada hubungan yang bermakna antara persepsi hambatan dengan perilaku kesehatan lansia hipertensi dan memiliki tingkat hubungan yang sedang. Hubungan antara kedua variabel menunjukkan adanya hubungan negatif antara perilaku kesehatan dan persepsi hambatan. Artinya apabila persepsi hambatan meningkat maka ada kecenderungan perilaku kesehatan hipertensi menjadi menurun.

Keputusan untuk mengambil tindakan/upaya penanggulangan atau pencegahan penyakit itu tergantung dari besar/kecilnya persepsi hambatan untuk melaksanakan tindakan itu dan pandangan individu tentang kemampuan diri sendiri.(Syukra Alhamda and Yustina Sriani, 2015) Seseorang tidak bertindak atau tidak melakukan kegiatan apa-apa (no action) karena mereka mempunyai alasan bahwa kondisi yang demikian tidak akan menggangu kegiatan atau kerja mereka sehari-hari, mereka beranggapan bahwa tanpa bertindak apa pun symptom atau gejala yang dideritanya akan lenyap dengan sendirinya. Tidak jarang pula masyarakat memprioritaskan tugas-tugas lain yang dianggap lebih penting dari pada mengobati sakitnya.

Alasan lain seseorang tidak bertindak atau tidak melakukan suatu kegiatan dalam upaya mengendalikan kesehatannya karena alasan fasilitas kesehatan yang diperlukan sangat jauh letaknya, para petugas kesehatan tidak simpatik, judes, tidak responsif, dan sebagainya. Hal ini juga menjadi alasan bagi responden yang tidak berperilaku sehat, yaitu merasa membebani keluarga, tempatnya jauh, biaya transportasi yang mahal dan membuang waktu. Dengan demikian semakin tinggi faktor hambatan akan semakin rendah pula perilaku sehat yang dilakukan oleh lanjut usia hipertensi.

\section{SIMPULAN}

Dari hasil penelitian menunjukkan bahwa sebagian besar responden mempunyai memiliki persepsi yang baik (persepsi keuntungan dan hambatan) dan juga memiliki perilaku kesehatan yang baik pula serta ada hubungan antara persepsi (keuntungan dan hambatan) dengan perilaku kesehatan. Semakin baik persepsi keuntungan akan meningkatkan perilaku sehat lanjut usia hipertensi dan sebaliknya semakin tinggi persepsi hambatan maka akan semakin rendah perilaku sehatnya. Bagi lanjut usia hipertensi perlu pemahaman yang lebih baik lagi tentang manfaat melakukan perilaku hidup sehat dan melakukan upaya-upaya yang dapat mengurangi berbagai hambatan untuk melakukan perilaku hidup sehat sehingga dapat mengontrol penyakit hipertensi yang dideritanya.

\section{DAFTAR PUSTAKA}

Afifa, I. (2019) 'Kinerja Kader dalam Pencegahan Stunting: Peran Lama Kerja sebagai Kader, Pengetahuan dan Motivasi', Jurnal Kedokteran Brawijaya. Brawijaya University, 30(4), p. 336. doi: 10.21776/ub.jkb.2019.030.04.19.

Dewi, S. R. (2014) Buku Ajar Keperawatan Gerontik. Yogyakarta: deepublish.

Dinkes Kab. Demak, P. M. (2019) Laporan SP2TP Puskesmas Mranggen tahun 2019.

GOVT (2017) 'Profil Kesehatan Provinsi Jawa Tengah 2017', Dinkes Jateng, 3511351(24), pp. 1-62. doi: 10.5606/totbid.dergisi.2012.10.

Husniyawati, Y. R. (2016) 'Analisis Pengaruh Motivasi, Komitmen dan Faktor Organisasi terhadap Kinerja Kader Posyandu (Studi tentang Peningkatan Partisipasi Ibu Balita di Posyandu Wilayah Kerja Puskesmas Sidotopo Wetan Kota Surabaya)'.

Kementrian Kesehatan RI (2018) 'Hasil Utama Laporan Riskesdas 2018', Jakarta: Badan Penelitian dan Pengembangan Kesehatan Departemen Kesehatan Republik Indonesia, p. 
22. doi: 1 Desember 2013.

Nugraheni, Hernien., wiyatini, tri., wiradona, irmanita. (2018) Kesehatan Masyarakat dalam Determinan Sosial Budaya - Hermien Nugraheni, Tri Wiyatini, \& Irmanita Wiradona Google Buku.

Nurmala, I. (2020) Promosi Kesehatan. Surabaya: Airlangga University Press.

Oktaviani, E. (2015) 'Pengaruh Brisk Walking Exercise Terhadap Penurunan Tekanan Darah Pada Penderita Hipertensi di Puskesmas Andalas Kota Padang', Keperawatan, 2(02), pp. $1-10$.

Riani, S. et al. (2013) Studi Deskriptif Status Mental Lansia berdasarkan Karakteristik Lansia di Kelurahan Karangayu Semarang barat, Karya Ilmiah.

Soesanto, E. (2012) 'Analisis Faktor-Faktor yang Berhubungan dengan Praktik Lansia Hipertensi dalam Mengendalikan Kesehatannya di Puskesmas Mranggen, Demak', FIKkeS, 3(2).

Soesanto, E. et al. (2018) 'Praktik Lansia Hipertensi dalam Mengendalikan Kesehatan Diri di Wilayah Puskesmas Mranggen Demak', Praktik Lansia Hipertensi dalam

Mengendalikan Kesehatan Diri di Wilayah Puskesmas Mranggen Demak. Master Program of Health Promotion Faculty of Public Health Diponegoro University, 5(2), pp. 127-139. doi: 10.14710/jpki.7.3.127-139.

Soesanto, E. and Abdurrahman, N. N. (2020) 'The Role of Volunteers in Improving Services in Elderly Integrated Service Centers', South East Asia Nursing Research, 2(1), p. 22. doi: 10.26714/seanr.2.1.2020.22-26.

Soesanto, E. and Sandra Fatmawati, D. (2019) 'Increased the Intensity of Elderly Visit to Posyandu with Family Support', South East Asia Nursing Research, 1(3). doi: 10.26714/seanr.1.3.2019.137-141.

Sulaiman, S. et al. (2018) 'Pendampingan Kader Posyandu Lansia di Suka Raya', Journal of Dedicators Community. Centre for Research and Community Development - Islamic University of Nahdlatul Ulama Jepara, 2(2), pp. 116-122. doi: 10.34001/jdc.v2i2.712.

Syukra Alhamda, S. K. M. M. K. and Yustina Sriani, S. K. M. M. P. H. (2015) Buku Ajar Ilmu Kesehatan Masyarakat (IKM). Deepublish. 